\title{
EFFECTS OF LEGUMES ON REPRODUCTION IN MICE
}

\author{
WENDELL W. LEAVITT AND PAUL A. WRIGHT \\ Agricultural Experiment Station, University of New Hampshire, \\ Durham, Nere Hampshire, U.S.A.
}

(Received 2nd Fanuary 1963)

\begin{abstract}
Summary. Ingestion of dried forage, incorporated into a Chow diet at a level of 15 or $30 \%$, induced infertility and reproductive anomalies in female mice. Conception rate in SWR/Jax mice was nil during a 22-day cohabitation with fertile males, as opposed to $57 \%$ conception in controls. The fertility of CD-1 male mice was not affected by Ladino. Vaginal and behavioural oestrus in CD-1 mice was inhibited for 18 or more days during feeding of $30 \%$ Ladino clover, but animals gradually adjusted whilst ingesting clover, and after 18 days oestrus reappeared and fertile matings occurred. Ingestion of $15 \%$ prebloom Ladino inhibited oestrus, but oestrus was more frequent and persistent than normal in mice receiving $15 \%$ second-growth Ladino. Feeding $30 \%$ mixed-growth Ladino for only 3 days caused a severe reduction in number of fertilized ova recoverable and a concomitant increase in degenerate ova; longer feeding frequently inhibited ovulation and sexual receptivity in spite of vaginal cornification. No single aqueous-alcoholic, etheralcoholic, chloroform, or acetone-chloroform extract of forages had any of the peculiar properties of the unfractionated plant, but all extracts increased the incidence of non-viable embryos.
\end{abstract}

\section{INTRODUCTION}

In recent years considerable attention has been focused on antifertility properties of forages, especially legumes. It is well established that various plants exhibit oestrogenic activity (Bradbury \& White, 1954) and that forages may contain amounts large enough to affect reproduction adversely (Bennetts, Underwood \& Shier, 1946; Pope, 1954). Following the isolation of genistein, East (1956) tested its effect on the fertility of mice and found that reproduction was impaired, males being more severely affected than females. Coumestrol seems to produce similar results (A. N. Booth, personal communication).

Fox, Kaufmes, Mason \& Oldfield (1957) reported reproductive failure in mice ingesting $40 \%$ red clover. Further work indicated that this reproductive disruption could not be explained in terms of oestrogenic or progestational effects or in terms of pituitary stimulation or inhibition alone. Swierstra (1958) caused breeding difficulties in mice by feeding alcoholic extracts of red clover and birdsfoot trefoil, and suggested that oestrogen-like substances were the causal agents. It is hoped that the present paper may clarify some apparent discrepancies. The work is a continuation of studies carried out by Wright 
(1960), but mice were used for comparative purposes and for further evaluation of mechanisms involved.

\section{MATERIALS}

Freshly-harvested plant material (i.e. leaves and/or bloom, but the bulk of weight consisting of petioles and leaflets) from plots in Northwood, New Hampshire, U.S.A., was dried for $12 \mathrm{hr}$ at $60^{\circ} \mathrm{C}$ in a convection oven and pulverized in a Wiley mill. Diets were compounded by addition of powdered forage to Purina Laboratory Chow, the basal ration, plant material being thoroughly blended in the diets by means of extensive hand-mixing.

Whenever extracts of forage were administered, they were added to the Chow diet in amounts which represented a definite equivalence of fresh plant material. Various organic solvents were then removed under vacuum and final equilibrium was brought about in an air current for 24 to $48 \mathrm{hr}$, with intermittent stirring. Water-soluble fractions were either stored at $4^{\circ} \mathrm{C}$ and added at each feeding, or were dried with Ghow in the convection oven.

All diets were fed as a wet paste in Petri dishes. Small platforms were constructed in the cages to hold the feeding dishes above the litter. This procedure afforded a minimum of contamination of the diets.

\section{EXPERIMENTAL PROCEDURES AND RESULTS}

FEEDING FORAGES IN THE DIET

Thirty-two mature SWR/Jax (Jackson Memorial Laboratory) females weighing 18 to $22 \mathrm{~g}$ were divided into four equal groups and housed four per cage. One group was fed on basal ration throughout and the remaining groups were fed on 15,30 and $60 \%$ (by weight) clover diets ( $5 \mathrm{~g} /$ mouse/day). After 7 days males were introduced, two per cage, and left with the females for 22 days, all groups being maintained on their respective rations. At the end of 22 days, the males were removed and the females continued on their respective diets through a theoretical gestation period (i.e. for an additional 22 days). Experimental females were regrouped with their respective males at the conclusion of the forage feeding period, and basal ration was substituted for the clover diets at that time.

No pregnancies occurred in experimental females during treatment with 15 and $30 \%$ diets, as compared to $50 \%$ pregnancies in controls. The $60 \%$ diet proved too unpalatable to the mice during the initial 7 days ( $21 \%$ weight loss), but $57 \%$ pregnancies subsequently resulted when control ration was substituted. Return to a fertile condition required about 5 days of readjustment after cessation of the experimental diet in these animals. In experiments which incorporated lower levels of Ladino clover in the diets, there were body weight losses proportional to the amount of clover in the diet $(16 \%$ on the $30 \%$ diet and $4 \%$ on the $15 \%$ diet). Weight gains began to appear after 18 days of feeding, indicating an adaptation to the experimental diets. Feeding of the basal diet, after 50 days of 15 or $30 \%$ Ladino clover diet, allowed $75 \%$ and $37 \%$ pregnancies, respectively, requiring the same period of readjustment, 4 to 5 days, as the animals which were briefly put on a $60 \%$ diet.

In order to explore these results in more detail, males and females were 
tested separately. Since SWR/Jax mice are highly inbred, fertility and number of offspring per litter were low. Therefore, GD-1 mice originating from an initial stock of gnotobiotic animals were used for comparative purposes and for further evaluation of the mechanism of effect.

Sixteen mature CD-1 males, ranging in age from 3 to 7 months, were divided into two equal groups. Each male was housed in an individual cage. One group was fed on a $30 \%$ Ladino diet and the other group on the control ration. After 5 days, each male was proffered, in the evening, an oestrous female (not of proven fertility) until a positive mating occurred or until four different females had been tried. Matings were determined by the presence of a copulation plug in the vagina or spermatozoa in a vaginal smear. Seven of eight Ladino-fed males mated with a record of 0.54 matings per trial. Six of the seven matings were fertile. All control males mated with a record of 0.67 matings per trial, and seven of the eight matings were fertile. The control males were subsequently fed on $30 \%$ Ladino for 5 days and mating trials were carried out as before. All eight mated with 0.62 matings per trial, and seven of the matings were fertile.

Vaginal smears were taken daily on mature GD-1 females for 12 days to check for regularity of oestrous activity. A $30 \%$ Ladino diet was then administered to eight of these, and upon the appearance of an oestrous smear, the female was placed with a male (of proven fertility) overnight. Copulation was determined as previously described. The first oestrous smear after beginning the Ladino diet occurred on Day 18 and all females had achieved oestrus by Day 23. The majority of animals did not mate immediately upon reappearance of vaginal oestrus. Six positive matings did eventually occur, and all were fertile. These resulted from thirteen trials at vaginal oestrus.

Ninety immature females were weaned at 18 days of age and started then on various $15 \%$ forage diets. A cellulose diet was included for comparison, as it was reasoned that the relatively large intake of vegetable matter was unnatural for the laboratory mouse and might constitute a type of dietary stress. Animals were caged at random in groups of five, and fed twice daily $(6 \mathrm{~g} / \mathrm{mouse} / \mathrm{day})$, in the early morning and evening. Body weights were recorded every other day. The animals were checked daily for vaginal introitus and vaginal smears were taken to determine the time of first oestrus and cyclic oestrous activity. One-half of the animals in each group were killed at 45 days of age, and the weights of both ovaries and adrenals were determined on a direct-reading analytical balance.

The data (Table 1) indicate a variety of effects from $15 \%$ forage diets. None of the diets significantly influenced the time of onset of vaginal patency, which averaged 31.0 days. It is interesting to note the trend within the Ladino groups. No significant oestrogenic activity was detected by separate bioassay in any of the samples at the levels used. A potentiation of endogenous oestrogenic response was manifested by more frequent and more persistent vaginal cornification in groups receiving second growth Ladino. Prebloom Ladino clearly inhibited oestrous activity, but bloom forage had neither stimulatory nor inhibitory properties. No useful data could be obtained from adrenal weights, but ovarian weight at Day 45 and $\log$ growth rate showed high correlation 
(Table 2). Neither ovarian weight nor growth rate were significant when considered individually. Whether or not these data indicate an effect on pituitary function must be determined by more critical experimentation.

Fifty-one CD-1 females 2 to 4 months old were selected for more detailed study of the effect of a $30 \%$ Ladino diet on reproductive physiology. Twenty-

TABLE 1

EFFECT OF 15\% FORAGE DIETS ON VAGINAL SMEARS IN YOUNG CD-1 MICE

\begin{tabular}{|c|c|c|c|c|c|}
\hline \multirow[t]{2}{*}{ Diet* } & \multirow[t]{2}{*}{$\begin{array}{c}\text { No. } \\
\text { smears }\end{array}$} & \multirow[t]{2}{*}{$\begin{array}{l}\text { No. } \\
\text { oestrous } \\
\text { smears }\end{array}$} & \multirow[t]{2}{*}{$\begin{array}{l}\text { No. } \\
\text { oestrous } \\
\text { cycles } \dagger\end{array}$} & $\begin{array}{l}\text { Oestrous } \\
\text { smears }\end{array}$ & \multirow{2}{*}{$\begin{array}{c}\text { Oestrus } \\
\text { occurring } \\
\text { by } 44 \text { days } \\
(\%)\end{array}$} \\
\hline & & & & No. smears & \\
\hline $\begin{array}{l}\text { Timothy } \\
\text { Phleum pratense } \\
\text { Alfalfa } \ddagger\end{array}$ & 95 & 18 & 15 & $0 \cdot 190$ & 80 \\
\hline $\begin{array}{l}\text { Medicago sativa } \\
\text { Cellulose } \\
\text { Ladino prebloom }\end{array}$ & $\begin{array}{l}176 \\
157\end{array}$ & $\begin{array}{l}24 \\
16\end{array}$ & $\begin{array}{l}16 \\
12\end{array}$ & $\begin{array}{l}0 \cdot 136 \\
0 \cdot 102\end{array}$ & $\begin{array}{l}80 \\
90\end{array}$ \\
\hline $\begin{array}{l}\text { Trifolium repens } \\
\text { Ladino bloom } \\
\text { Ladino second growth }\end{array}$ & $\begin{array}{l}125 \\
144\end{array}$ & $\begin{array}{r}6 \\
19\end{array}$ & $\begin{array}{r}5 \\
11\end{array}$ & $\begin{array}{l}0.048 \\
0.132\end{array}$ & $\begin{array}{l}44 \\
70\end{array}$ \\
\hline $\begin{array}{l}\text { July } \\
\text { Ladino second growth }\end{array}$ & 121 & 21 & 16 & $0 \cdot 174$ & 100 \\
\hline $\begin{array}{l}\text { late August } \\
\text { Control }\end{array}$ & $\begin{array}{l}155 \\
283\end{array}$ & $\begin{array}{l}35 \\
42\end{array}$ & $\begin{array}{l}25 \\
31\end{array}$ & $\begin{array}{l}0.226 \\
0.149\end{array}$ & $\begin{array}{r}100 \\
95\end{array}$ \\
\hline
\end{tabular}

- Ladino prebloom $=$ nine animals; Control = twenty animals; All other groups $=$ ten animals.

$\dagger$ In some cases oestrous smears occurred on consecutive days. The value given here is the number of vaginal oestrous cycles.

$\ddagger$ Oestrogenic as measured by immature mouse bioassay.

$\$$ Purified ashless powder.

TABLE 2

EFFECT OF $15 \%$ FORAGE DIETS ON OVARIAN WEIGHT AND GROWTH RATE IN CD-1 MICE

\begin{tabular}{l|c|c}
\hline \multicolumn{1}{c|}{ Diet } & $\begin{array}{c}\text { Ovarian weight } \\
(\text { mean } \pm \text { s.D. } \\
(\mathrm{mg})\end{array}$ & $\begin{array}{c}\text { Growth rate in } \\
\text { log growth phase } \\
\text { (Average } \text { g gained/day) }\end{array}$ \\
\hline Timothy & $5 \cdot 8 \pm 1 \cdot 1$ & 0.65 \\
Alfalfa & $6 \cdot 7 \pm 1 \cdot 6$ & 0.69 \\
Cellulose & $7 \cdot 2 \pm 1 \cdot 4$ & 0.79 \\
Ladino, August & & 0.81 \\
\hline (second growth) & $7 \cdot 4 \pm 1 \cdot 5$ & 0.99 \\
\hline Control & $8.4 \pm 2 \cdot 1$ & \\
\hline
\end{tabular}

eight of these were used for egg counts performed 34 to $37 \mathrm{hr}$ post coitum in the manner described by Lewis \& Wright (1935). Two experimental procedures were devised: (1) Five animals were started on clover diets at early pro-oestrus and mating trials were attempted at oestrus approximately $1 \frac{1}{2}$ days later. (2) Thirteen mice were fed a clover diet for 11 to 22 days, with mating trials commencing at the first oestrus after 11 days of treatment. 
Ladino's influence on fertilization and survival of ova is depicted in Table 3. Under temporary treatment (Group A), the number of abnormal ova increased, resulting in only $53 \%$ fertilized ova being recovered. After prolonged treatment

TABLE 3

EFFECT OF Ladino ON OVA OF CD-1 MICE

\begin{tabular}{|c|c|c|c|c|c|}
\hline \multirow{3}{*}{$\begin{array}{l}\text { Ova from } \\
\text { Receptive } \\
\text { females in oestrus } \\
\text { (mated) }\end{array}$} & \multicolumn{2}{|c|}{ Condition of ova } & Control & Ladino $A^{*}$ & Ladino $B^{*}$ \\
\hline & \multirow{2}{*}{ Normal } & 2-cell $\dagger$ & $49 \quad(8)_{\ddagger}^{+}$ & $26(4)$ & $31 \quad(6)$ \\
\hline & & 1-cell & 5 & 4 & 12 \\
\hline & \multicolumn{2}{|c|}{ Abnormal } & 2 & 19 & 4 \\
\hline \multirow{2}{*}{$\begin{array}{l}\text { Non-receptive } \\
\text { females in oestrus }\end{array}$} & Normal & 1-cell & $16(2)$ & $0(1)$ & $12(7) \$$ \\
\hline & \multicolumn{2}{|c|}{ Abnormal } & 1 & 10 & 20 \\
\hline
\end{tabular}

* Diet A given for $36 \mathrm{hr}$ prior to mating, Diet B given for 11 to 22 days prior to mating.

+ Two-cell ova were considered fertilized. No data were collected to indicate the number of non-viable ova represented by these figures.

$\ddagger$ Number of animals in parentheses.

$\S$ Three of these animals did not ovulate.

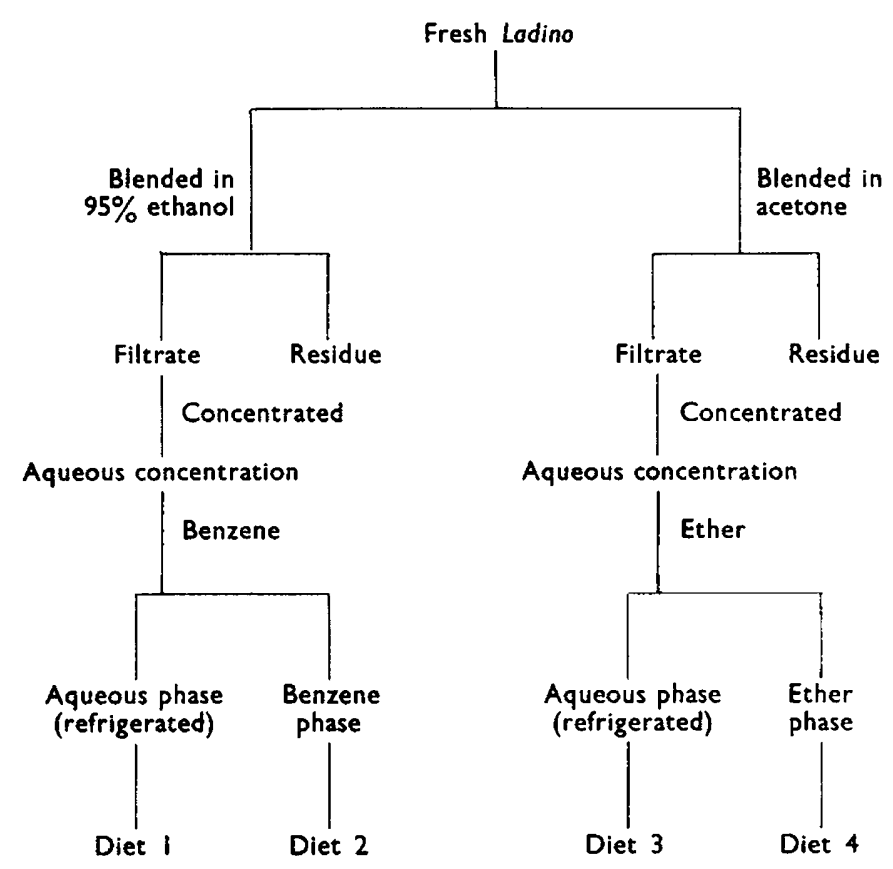

Text-FIg. 1. Outline for Experiment 1 diet preparation.

(Group B), $66 \%$ were fertilized, and abnormal ova had returned to a normal level. Attention should be drawn to the fact that three of seven mice in Group B (non-copulating, oestrous animals) did not ovulate. A higher incidence of abnormal ova was noted in non-receptive animals from both groups. 
FEEDING FORAGE EXTRACTS IN THE DIET

Diets were prepared with various fractions of legume, as shown in Text-figs. 1 and 2. Experiment 1 was designed to investigate fresh material and to compare fractionation procedures. Two different dried legumes were compared in Experiment 2. The Ladino meal sample contained no significant oestrogenic activity as measured by an immature mouse bioassay. The alfalfa sample had an activity equal to $0 \cdot 02 \mu \mathrm{g}$ diethylstilboestrol/g. Since all diets were prepared with doses of extracted material equivalent to levels in the original source (i.e. fresh or dried legume), those tested in Experiment 2 contained higher concentrations of extract that those in Experiment 1. Each diet was tested on eight or more mice with proven oestrous activity. Vaginal smears, and mating trials with males known to be fertile, were carried out as before with CD-1 females.

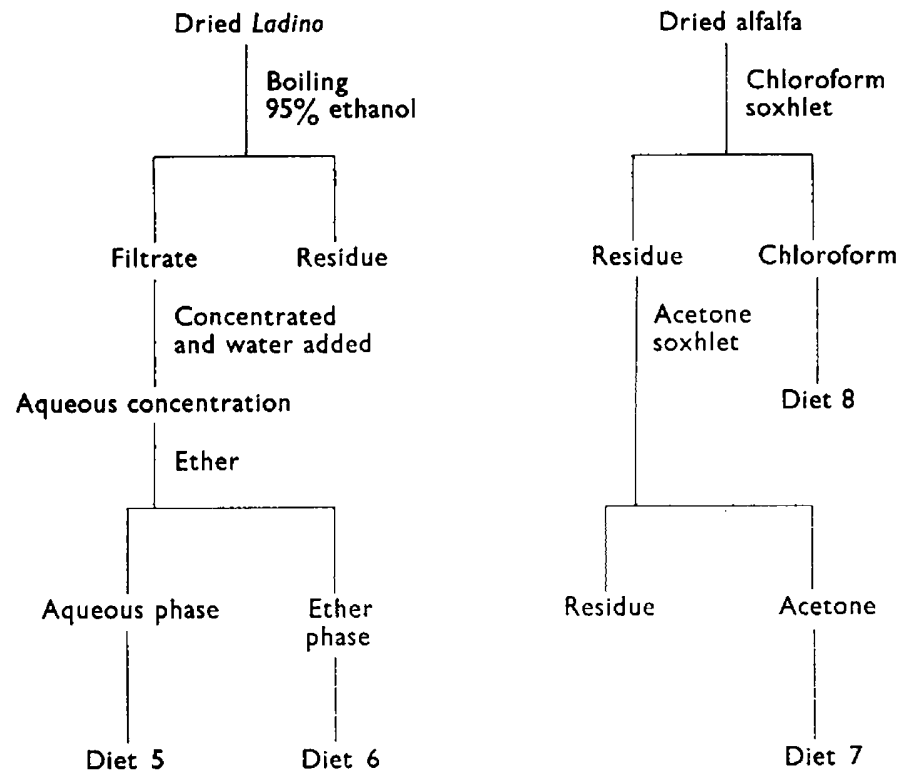

TexT-Fig. 2. Outline for Experiment 2 diet preparation.

Seven days were allowed for adjustment at the onset of experimental feeding, with matings attempted at each oestrus during treatment (22 to 35 days). Conceptions resulting in Experiment 1 were not disturbed, whereas pregnancies in Experiment 2 were terminated 15 days post coitum. Viable embryos were weighed at autopsy and the characteristics of non-viable embryos were noted.

None of the extracts in Experiment 1 exhibited any of the peculiar properties of whole Ladino. One animal on Diet 2 and one on Diet 4 became pseudopregnant, but no pseudopregnancies were noted in the other twenty-eight animals tested in this part of our research. Again in Experiment 2 there was no suppression of oestrous cycles, but one pseudopregnancy resulted from Diet 6 (Ladino) and three were produced by Diet 8 (alfalfa). No repeat breeders were noted among the remaining animals. In both extract experiments there was no significant difference in number of conceptions or in litter size. Feed 
consumption data indicated that Diets 5 and 8 were unpalatable but not enough to cause weight losses. Table 4 shows that there was an increase in number of non-viable embryos in all females on extract diets in Experiment 2.

Bickoff, Livingston, Booth, Hendrickson \& Kohler (1960) have pointed out that the oestrogenic response obtained when a crude forage extract is assayed represents a summation of effects of oestrogen inhibitors and potentiators,

TABLE 4

RESULTS OF EXTRACT EXPERIMENT 2 AT 15TH DAY OF PREGNANCY

\begin{tabular}{|c|c|c|c|c|c|}
\hline Diet* & $\begin{array}{c}\text { Wt. mice } \\
\text { before } \\
\text { treatment } \\
(\mathrm{g})\end{array}$ & $\begin{array}{c}\text { Wt. gain } \\
\text { at Day } 15 \\
\text { pregnancy } \\
(\mathrm{g})\end{array}$ & $\begin{array}{c}\text { No. } \\
\text { viable } \\
\text { embryos }\end{array}$ & $\begin{array}{c}\text { Wt. } \\
\text { viable } \\
\text { embryos } \\
(g)\end{array}$ & $\begin{array}{c}\text { No. } \\
\text { non-viable } \\
\text { embryos } \dagger\end{array}$ \\
\hline $\begin{array}{c}\text { Basal } \\
5 \\
6 \\
7 \\
8\end{array}$ & $\begin{array}{l}36 \cdot 4 \\
36 \cdot 4 \\
37 \cdot 5 \\
34 \cdot 2 \\
35 \cdot 5\end{array}$ & $\begin{array}{r}11.0 \\
10 \cdot 1 \\
11 \cdot 2 \\
9.8 \\
9.0\end{array}$ & $\begin{array}{r}10.9 \\
11 \cdot 0 \\
11 \cdot 6 \\
9.8 \\
10 \cdot 1\end{array}$ & $\begin{array}{l}0 \cdot 256 \\
0 \cdot 245 \\
0 \cdot 299 \\
0 \cdot 285 \\
0 \cdot 262\end{array}$ & $\begin{array}{l}0.75 \\
1.49 \\
1.25 \\
1.20 \\
1.36\end{array}$ \\
\hline
\end{tabular}

* Eight animals per diet. All figures are group averages.

$\uparrow$ Includes resorptions and embryos dead at time of autopsy.

TABLE 5

BIOASSAYS WITH IMMATURE CD- 1 MICE OVARIEGTOMIZED AT 18 DAYS AND TREATED FOR 6 DAYS

\begin{tabular}{|c|c|c|c|c|c|}
\hline Treatment & $\begin{array}{c}\text { No. } \\
\text { animals }\end{array}$ & $\begin{array}{c}\text { Vaginal } \\
\text { patency } \\
\text { at } \\
25 \text { days }\end{array}$ & $\begin{array}{c}\text { Average } \\
\text { uterine } \\
\text { weight } \\
(m g)\end{array}$ & $\mathrm{P}$ value & $\begin{array}{c}\text { Average } \\
\text { weight at } \\
25 \text { days } \\
(\mathrm{g})\end{array}$ \\
\hline $\begin{array}{l}\text { Basal diet } \\
\text { 'Alfalfa'* } \\
\text { Diet } 5 \\
\text { Diet } 6 \\
\text { Diet } 7 \\
\text { Diet } 8 \\
0.01 \mu g \text { DEs } / \mathrm{g} \\
0.03 \mu g \text { DEs/g } \\
0.06 \mu \mathrm{g} \text { DES/g }\end{array}$ & $\begin{array}{r}10 \\
6 \\
6 \\
6 \\
6 \\
6 \\
7 \\
6 \\
6\end{array}$ & $\begin{array}{l}0 \\
6 \\
0 \\
0 \\
2 \\
0 \\
0 \\
3 \\
6\end{array}$ & $\begin{array}{r}7 \cdot 79 \\
12.66 \\
7 \cdot 72 \\
7 \cdot 81 \\
10 \cdot 20 \\
9 \cdot 28 \\
11 \cdot 08 \\
24 \cdot 73 \\
59 \cdot 90\end{array}$ & $\begin{array}{l}<0.05 \\
<0.05 \\
<0.01 \\
<0.01\end{array}$ & $\begin{array}{l}17 \cdot 3 \\
17 \cdot 8 \\
17 \cdot 0 \\
17 \cdot 0 \\
17 \cdot 0 \\
12 \cdot 9 \uparrow \\
17 \cdot 1 \\
17 \cdot 0 \\
17 \cdot 3\end{array}$ \\
\hline
\end{tabular}

* Acetone Soxhlet extract similar to Diet 8 preparation.

$\uparrow$ Significance, $P=0.01$.

$\ddagger$ DES $=$ diethylstilboestrol.

together with that of the oestrogenic compounds in the forage. With this in mind only raw data from bioassays are presented in Table 5. Records of premature vaginal opening can be regarded as additional evidence of oestrogenic response when taken in conjunction with other results (East, 1956), and are included. Only Diet 7 produced significant oestrogenic response. Feed consumption and weight gain were significantly reduced by chloroform extract (Diet 8 ). In contrast, the acetone extract of the same alfalfa sample exhibited none of these effects. 


\section{DISCUSSION}

From the above results it is clear that whole legume may influence reproduction in several ways, but at this stage of experimentation only trends and not detailed explanations can be presented. A report by McClure (1958) on temporary nutritional stress and infertility in mice may be pertinent. Pituitary gonadotrophins have been shown to be very sensitive to the effects of malnutrition (Davies, 1960). Suppression of oestrous cycles by Ladino was similar to the effects of a $15 \%$ Lithospermum diet (Drasher \& Zahl, 1946). In this latter study, strain differences were found, namely, $\mathrm{C} 3 \mathrm{H}$ females were thrown into persistent anoestrus whilst the Rockland strain of animals developed varying degrees of refractoriness to treatment. It would seem, therefore, that the 'infertility' produced by feeding unfractionated legume in the diet is not a true manifestation of hormone-like substances present in the plant, but possibly a nutritional stress mainly influencing pituitary function. Results substantiating this concept are weight losses upon initial treatment, suppression of oestrous cycles, production of abnormal ova, and a reduction in mating behaviour.

Whether or not oestrogenic activity in Ladino and alfalfa is responsible for impaired reproductive performance is still questionable. The preliminary work presented in this paper indicates that the minimal oestrogenic activity usually found in these legumes (Diet 7) does not significantly influence reproduction in female mice. Pseudopregnancy occurred with low but consistent frequency in animals consuming extracts prepared with organic solvents. No pseudopregnancies were noted in animals receiving basal ration or diets containing aqueous extracts. It is felt that this observation is worthy of further experiment and evaluation. It would seem likely that other materials of unknown identity, but soluble in several organic solvents, are responsible for these results. Work along this line is in progress.

Ershoff, Hernandez \& Matthews (1956) suggested the presence of an oestrogen inhibitor in dried alfalfa. The results of feeding prebloom Ladino to weanling female mice also indicate the existence of an oestrogen inhibitor in this species of plant, but other samples of Ladino acted as potentiators of endogenous oestrogenic activity, even though they did not show oestrogenic activity in bioassay. Bickoff et al. (1960) have noted oestrogen inhibitors and potentiators in crude forage extracts. It is possible that the repeated occurrence of pseudopregnancies in the experiments with extracts could have resulted from the action of such substances and not from any oestrogenic substances per se.

Ostrovsky \& Kitts (1962) point out that no single oestrogenic compound can be regarded as accurately representing the oestrogenicity of a forage with respect to potency or to spectrum of activity. The results in Table 5 show alfalfa extracts to be much more effective in hastening vaginal patency than in stimulating uterine weight increases. It is still possible that hormone-like substances exist which are not effectively measured by uterine weight assay but are active in influencing reproductive phenomena.

While seeming to answer some controversial points, our studies have at the same time left many unanswered questions. Problems relating to (1) interrelationships between nutritional factors and endogenous and exogenous oestrogens, (2) digestibility and relative nutritional value of diets and extracts, 
and (3) effects of pituitary cytology, hormone content, and function are receiving current attention. Srebnik \& Nelson (1962) have demonstrated clear effects on pituitary function by restriction of dietary protein. Could forage diets be guilty of a similar lack or imbalance? We also know nothing of the vitamin content of diets and extracts; could some of the reproductive anomalies which have been observed be due to vitamin deficiencies and imbalance, as suggested by Lutmak-Mann (1958) ? We have also to bear in mind the possibility of wide variation among different samples of forage crop resulting from varying climatic conditions, soil factors, illumination, or even rainfall.

\section{ACKNOWLEDGMENTS}

This paper is published with the approval of the Director of the New Hampshire Agricultural Experiment Station as Scientific Contribution No. 301. The work was supported in part by Regional Research Funds under NE-41, Endocrine Factors Affecting Reproduction in the Bovine Female. Thanks are due to the many who made valuable suggestions and criticisms.

\section{REFERENCES}

Bennetrs, H. W., Underwood, G. J. \& Shier, F. L. (1946) A specific breeding problem of sheep on subterranean clover pastures in Western Australia. Aust. vet. 7. $22,2$.

Bickoff, E. M., Lrvingston, A. L., Booth, A. N. Hendrickson, A. P. \& Kohler, G. O. (1960) Estrogenic activity in dehydrated and suncured forages. F. Anim. Sci. 19, 189.

Bradbury, R. B. \& White, D. E. (1954) Estrogens and related substances in plants. Vitam. Horm. 12, 207.

DAvies, J. (1960) Survey of research in gestation and the developmental sciences, p. 194. Williams \& Wilkins, Baltimore.

Drasher, M. L. \& Zahl, P. A. (1946) The effect of Lithospermum on the mouse estrous cycle. Proc. Soc. exp. Biol., N.r. 63, 66.

East, J. (1956) The effect of genistein on the fertility of mice. f. Endocrin. 13, 94.

Ershoff, B. H., Hernandez, H. J. \& Matthews, J. H. (1956) Beneficial effects of alfalfa on the ovarian development of immature rats fed massive doses of a-estradiol. 7 . Nutr. 59, 147.

Fox, C. W., Kaufmes, J., Mason, R. W. \& Oldfield, J. E. (1957) Effects of feeding red clover (Trifolium pratense) on reproduction in laboratory mice. Proc. Amer. Soc. Anim. Prod. (Western Section), 8, xliv.

Lewis, W. H. \& Wright, E. S. (1935) On the early development of the mouse egg. Carnegie Instn Wash. Publ. 25, 113.

Lutmak-ManN, C. (1958) The dependence of gonadal function upon vitamins and other nutritional factors. Vitam. Horm. 16, 35.

McClure, T. J. (1958) Temporary nutritional stress and infertility in mice. Nature, Lond. $181,1132$.

Ostrovsky, D. \& KrTts, W. D. (1962) Estrogen-like substances in legumes and grasses: The influence of fractionation and route of administration on the estrogenic activity of plant materials. Canad. J. Biochem. 40, 159.

Pope, G. S. (1954) The importance of pasture plant oestrogens in the reproduction and lactation of grazing animals. 7. Dairy Sci. (Abstracts), 16, 333.

SRebnik, H. H. \& Nelson, M. M. (1962) Anterior pituitary function in male rats deprived of dietary protein. Endocrinology, 70, 723.

Swierstra, E. E. (1958) The estrogen-like substances in various legumes and grasses, and the effect of these compounds on the reproduction and growth of certain laboratory animals. Master's thesis, University of British Columbia.

WRIGHT, P. A. (1960) Infertility in rabbits induced by feeding Ladino clover. Proc. Soc. exp. Biol., N.Y. $105,428$. 